\title{
Goat cheese yield and recovery of fat, protein, and total solids in curd are affected by milk coagulation properties
}

\author{
Giuseppe M. Vacca, ${ }^{1} \odot$ Giorgia Stocco, ${ }^{1} \odot$ Maria L. Dettori, ${ }^{1} \oplus$ Giovanni Bittante, ${ }^{2} \odot$ and Michele Pazzola ${ }^{1 *}$ (]) \\ ${ }^{1}$ Department of Veterinary Medicine, University of Sassari, 07100 Italy \\ ${ }^{2}$ Department of Agronomy, Food, Natural resources, Animals and Environment (DAFNAE), University of Padova, 35020 Legnaro, Italy
}

\begin{abstract}
The aims of the present research were to quantify the effects of each coagulation trait, traditional milk coagulation properties [MCP: rennet coagulation time (RCT), curd-firming time $\left(\mathrm{k}_{20}\right)$, and curd firmness at $30 \mathrm{~min}\left(\mathrm{a}_{30}\right)$ ], and modeled curd-firming over time $\left(\mathrm{CF}_{\mathrm{t}}\right)$ parameters [estimated rennet coagulation time $\left(\mathrm{RCT}_{\mathrm{eq}}\right)$, curd-firming instant rate constant $\left(\mathrm{k}_{\mathrm{CF}}\right)$, and potential curd firmness $\left.\left(\mathrm{CF}_{\mathrm{P}}\right)\right]$ directly on the following: (1) recovery of 3 milk components in the curd (\%REC), (2) 3 measures of cheese yield (\%CY), and (3) 3 daily cheese yield traits (dCY) from goat milk. Cheese-making traits were analyzed using 2 mixed different models, the first to test MCP and the second to test $\mathrm{CF}_{\mathrm{t}}$ parameters. Pearson correlations were also calculated. Significant and favorable relationships (negative for time intervals and positive for $\mathrm{CF}$ measures) were found between the traditional MCP and the $\mathrm{CF}_{\mathrm{t}}$ parameters and $\% \mathrm{REC}$ and $\% \mathrm{CY}$ traits. The effects of milk fat and protein contents were particularly important on all cheese-making traits, with the only exception being the effect of fat content on water retention in cheese $\left(\% \mathrm{CY}_{\text {WATER }}\right)$. We found an optimum value of milk $\mathrm{k}_{20}$, associated with the highest recovery of components and cheese yield in solids (\% $\mathrm{CY}_{\text {SOLIDS }}$ ). In addition, a lower level of curd water retention and an increased fresh curd yield $\left(\% \mathrm{CY}_{\mathrm{CURD}}\right)$ were associated with greater recovery of fat. The collection of all available information during the process of milk coagulation and curd-firming allowed us to discover the effect of $\mathrm{RCT}_{\text {eq }}$ on \% REC traits and \% $\mathrm{CY}_{\text {SOLIDS, }}$, which had not previously been revealed for traditional RCT. Moreover, higher $\mathrm{k}_{\mathrm{CF}}$ values were associated with increased $\% \mathrm{CY}_{\mathrm{CURD}}$ and $\% \mathrm{CY}_{\text {SOLIDS }}$. Given that $\mathrm{CF}_{\mathrm{t}}$ parameters showed a high level of independence from one another, these can also be easily used and characterized in future applications at the industry level. Information provided
\end{abstract}

Received February 4, 2019.

Accepted October 26, 2019.

*Corresponding author: pazzola@uniss.it by traditional and modeled coagulation properties could efficiently support the goat dairy industry and lay the foundations for a quality payment scheme for goat milk.

Key words: rennet coagulation time, curd firmness, curd-firming time, modeling

\section{INTRODUCTION}

Milk fat and protein contents, together with casein genetic variants, are the major contributors to cheese yield (\%CY; Guo et al., 2004; Wedholm et al., 2006) and to the recovery of each component (\%REC) from milk in the curd (Pazzola et al., 2019). Milk composition also strongly affects milk coagulation properties (MCP; Caravaca et al., 2011; Stocco et al., 2018b; Amalfitano et al., 2019). However, the actual relationship between MCP and cheese-making traits is yet to be clarified.

The available research on bovine milk does not resolve the contradictory results about coagulation traits and $\% \mathrm{CY}$, nor does it fill in the lack of information about those aspects of the cheese-making process that enhance \%CY, such as the recovery of each milk component in the curd. Indeed, no information is available for goats on the effect of coagulation traits on recovery of fat, protein, and total solids in the curd. Since the 1980s, bovine MCP have been evaluated using mechanical lactodynamographs, but only in the last few decades has research been conducted on MCP from small ruminants (Bencini, 2002; Mestawet et al., 2013; Inglingstad et al., 2014). The lactodynamograph is the instrument most commonly used at laboratory level to assess MCP of a large number of milk samples per day. This instrument simulates the cheese-making process through the heating of milk and the addition of rennet, and records 3 single-point traits: rennet coagulation time (RCT, min), curd-firming time $\left(\mathbf{k}_{\mathbf{2 0}}\right.$, min), and curd firmness 30 min after enzyme addition $\left(\mathbf{a}_{\mathbf{3 0}}, \mathbf{m m}\right.$; McMahon and Brown, 1982). However, the traditional single-point MCP are sometimes considered ineffective for evaluating milk from small ruminants, 
because the coagulation process is faster in their milk than in the milk of cows. In the meantime, the development of computerized lactodynamographs recording 1 value of curd firmness (CF) every $15 \mathrm{~s}$ has made more information available. Thus, to provide new insights into the MCP of small ruminants, the model proposed by Bittante (2011), using all the CF values available for each milk sample, has been successfully applied to the coagulation process of milk samples from sheep and goats (Bittante et al., 2014; Vacca et al., 2015; Pazzola et al., 2018). That model provides 3 novel parameters: the asymptotic potential value of curd firmness at an infinite time $\left(\mathbf{C F}_{\mathbf{P}}, \mathbf{m m}\right)$, the curd-firming instant rate constant $\left(\mathbf{k}_{\mathrm{CF}}, \%\right.$ per min), and the RCT predicted from the modeling of all available data $\left(\mathbf{R C T}_{\mathbf{e q}}, \mathrm{min}\right)$.

In the literature, there is no general agreement about the effect of MCP on cheese-making traits. NgKwai-Hang et al. (1989) report that MCP are weakly correlated with moisture-adjusted CY. Johnson et al. (2001) have found that slow RCT are associated with increases in cheese moisture and cheese yield, and that the percentage of fat recovered in cheese is inversely correlated with curd firmness. Ikonen et al. (1999) suggest that improvement of bulk MCP would improve the efficiency of cheese-making, although several factors are confounded (i.e., milk composition, herd groups). Moreover, to date, there have been no reliable results for goats about this topic, so new information is needed to increase our knowledge, especially for the goat dairy industry. The present research was carried out to directly quantify the effects of each coagulation trait, traditional ( $\mathrm{RCT}, \mathrm{k}_{20}$, and $\left.\mathrm{a}_{30}\right)$ and modeled $\left(\mathrm{RCT}_{\text {eq }}\right.$, $\mathrm{k}_{\mathrm{CF}}$, and $\mathrm{CF}_{\mathrm{P}}$ ), on the following: (1) recovery of 3 milk components (fat, protein, and total solids) in the curd (\%REC), (2) 3 measures of cheese yield (\%CY), and (3) 3 daily cheese yield traits ( $\mathbf{d C Y})$ from goat milk.

\section{MATERIALS AND METHODS}

\section{Milk Sampling and Laboratory Analyses}

A total of 560 individual milk samples were collected from goats belonging to 6 different breeds (Saanen, Camosciata delle Alpi, Murciano-Granadina, Maltese, Sarda, and Sarda Primitiva) and reared on 35 Sardinian farms (Italy). Details of farm characteristics and description of the breeds have been previously reported by Vacca et al. (2018a). In brief, farms were of 3 management types: 14 farms were traditionally managed (extensive system, grazing of natural pastures, familyoperated); 11 were intermediate (semiextensive system, control of kidding season); and 10 were modern (semiintensive system, housing in modern buildings, use of
TMR, out-of-season kidding, operated by hired workers, consultancy of experts in animal feeding).

Milk fat, protein, and total solids were determined using a MilkoScan FT6000 milk analyzer (Foss Electric A/S, Hillerød, Denmark) calibrated according to FILIDF references (ISO-IDF, 2010; ISO-IDF, 2013).

The laboratory milk cheese-making assessment (9-MilCA) proposed by Cipolat-Gotet et al. (2016b) was used to measure single-point MCP, \%REC, and $\% \mathrm{CY}$ traits. The following procedure was performed with 2 replicates each, of 560 individual milk samples (2 aliquots of $9 \mathrm{~mL}$ of the same milk sample), for a total of 1,120 analyses. Each milk replicate $(9 \mathrm{~mL})$ was poured into a glass tube, inserted into the modified sample rack of the lactodynamograph instrument, heated to $35^{\circ} \mathrm{C}$ for $15 \mathrm{~min}$, and mixed with $0.2 \mathrm{~mL}$ of a rennet solution [Hansen Standard 215, with $80 \pm 5 \%$ chymosin and $20 \pm 5 \%$ pepsin; 215 international milk clotting units (IMCU)/mL (Pacovis Amrein AG, Bern, Switzerland); diluted to $1.2 \%$ (wt/vol) in distilled water]. The sample rack was then moved to the lactodynamograph set at $35^{\circ} \mathrm{C}$, for a 30 -min duration test. The recorded MCP were as follows: RCT, as the time interval between rennet addition and gelation; $\mathrm{k}_{20}$, as the time between gelation and the achievement of curd firmness of $20 \mathrm{~mm}$; $\mathrm{a}_{30}$, as curd firmness at $30 \mathrm{~min}$ after rennet addition.

At the end of the analysis, coagulated replicates of milk samples were manually cut using a steel spatula and moved to the heater at $55^{\circ} \mathrm{C}$, for the 30 -min curdcooking phase. During the cooking phase, each replicate was subjected to a further manual cutting by the same operator, and the curd particles were allowed to sit quiescently in their own whey after cutting. At the end, each glass tube was removed from the sample rack, and the curd was separated from the whey. The curd was pressed and suspended above the whey for 15 min at room temperature to favor the draining. The obtained curd and whey were weighed using a precision scale. Whey composition was assessed using an infrared spectrophotometer (MilkoScan FT2, Foss Electric). The weights of the curd and whey (g) and the chemical composition of milk and whey also allowed us to estimate curd composition by calculating the difference between milk and whey contents. The cheese yield (\%CY) traits were $\mathbf{\%} \mathbf{C Y}_{\mathbf{C U R D}}, \mathbf{\%} \mathbf{C Y}_{\text {SOLIDS }}$, and $\mathbf{\%} \mathbf{C Y}_{\text {WATER }}$, calculated as the ratios of the weight $(\mathrm{g})$ of fresh curd, curd DM, and water retained in curd, respectively, to the weight of the milk processed (g), multiplied by 100 . The component recovery (\%REC) traits were as follows: $\%$ REC $_{\text {PROTEIN }}, \%$ REC $_{\text {FAT }}$, and $\%$ REC $_{\text {SOLIDS }}$, calculated as the ratios of the weight (g) of the curd components (protein, fat, and DM, respectively) to the same component of milk (g), and multiplied by 100 . 
Daily cheese yields $\left(\mathrm{dCY}_{\mathrm{CURD}}, \mathrm{dCY}_{\text {SOLIDS }}\right.$, and $\mathrm{dCY} \mathrm{YATER}_{\text {WA }} \mathrm{kg} / \mathrm{d}$ ) were calculated by multiplying the $3 \% \mathrm{CY}$ traits $\left(\% \mathrm{CY}_{\mathrm{CURD}}, \% \mathrm{CY}_{\mathrm{SOLIDS}}\right.$, and $\% \mathrm{CY}_{\mathrm{WATER}}$, respectively) by the daily milk yield of each goat.

\section{Modeling of Curd Firmness}

The 3-parameter model (Bittante, 2011) was applied to the 120 individual point observations of curd firmness recorded by the Formagraph (Foss Italia S.P.A., Padova, Italy) during the lactodynamographic analysis (curd firmness recorded every $15 \mathrm{~s}$ ). During a 30-min test, 120 individual curd firmness observations are recorded for each milk sample. The model tested was as follows:

$$
\mathrm{CF}_{\mathrm{t}}=\mathrm{CF}_{\mathrm{P}} \times\left[1-\mathrm{e}^{-\mathrm{k}_{\mathrm{CF}} \times\left(\mathrm{t}-\mathrm{RCT}_{\mathrm{eq}}\right)}\right],
$$

where $\mathrm{CF}_{\mathrm{t}}$ is curd firmness at time $t(\mathrm{~mm}) ; \mathrm{CF}_{\mathrm{P}}$ is the asymptotic potential value of $\mathrm{CF}$ at an infinite time $(\mathrm{mm}) ; \mathrm{k}_{\mathrm{CF}}$ is the curd-firming instant rate constant $(\%$ per min); and $\mathrm{RCT}_{\text {eq }}$ is RCT estimated by $\mathrm{CF}_{\mathrm{t}}$ equation on the basis of all data points (min). Because the model uses all information available from the lactodynamographic analysis, the 3 estimated parameters are not single-point measurements, as the traditional MCP are. The parameter $\mathrm{CF}_{\mathrm{P}}$ is conceptually independent from both test duration and RCT, unlike $\mathrm{a}_{30}$. The parameter $\mathrm{k}_{\mathrm{CF}}$ describes the shape of the curve from the time of coagulation using all available $\mathrm{CF}$ points and provides information about the speed of the process. Last, the parameter $\mathrm{RCT}_{\mathrm{eq}}$ is the equivalent trait of the traditional RCT trait, but here it is estimated using all available data.

\section{Statistical Analysis}

Curvilinear regressions were fitted to the $120 \mathrm{CF}_{\mathrm{t}}$ observations available for each sample and analyzed using the nonlinear procedure (PROC NLIN) of SAS version 9.4 (SAS Institute Inc., Cary, NC). The parameters of each individual equation were estimated by employing the Marquardt iterative method, with 350 iterations and $10^{-5}$ level of convergence.

Cheese-making traits from 560 milk samples in 2 replicates, for a total of 1,120 analyses, were analyzed using a MIXED procedure in SAS, according to the following model:

$$
\begin{array}{r}
\mathrm{Y}_{\text {efghijklmnop }}=\mu+\text { DIM }_{\mathrm{e}}+\text { Parity }_{\mathrm{f}}+\text { Fat }_{\mathrm{g}}+\text { Protein }_{\mathrm{h}} \\
+\mathrm{RCT}_{\mathrm{i}}+\mathrm{k}_{20 \mathrm{j}}+\mathrm{a}_{30 \mathrm{k}}+\text { Farm }_{\mathrm{l}}+\text { Breed }_{\mathrm{m}}+\text { Animal }_{\mathrm{n}} \\
+{\text { Glass } \text { Tube }_{\mathrm{o}}}+\mathrm{e}_{\text {efghijklmnop }},
\end{array}
$$

in which $\mathrm{Y}_{\text {efghijklmno }}$ is the observed trait (\%CY, \%REC, $\mathrm{dCY}) ; \mu$ is the overall intercept of the model; $\mathrm{DIM}_{\mathrm{e}}$ is the fixed effect of the eth class of days in milk ( $\mathrm{e}=1$ to 4, as reported in Pazzola et al., 2019); Parity $y_{\mathrm{f}}$ is the fixed effect of the fth parity ( $\mathrm{f}=1$ to 3; Pazzola et al., 2019); Fat is the fixed effect included in the model as linear covariate; Protein $_{\mathrm{h}}$ is the fixed effect included in the model as linear covariate; $\mathrm{RCT}_{\mathrm{i}}$ is the fixed effect of the ith class of RCT ( $i=7$ classes); $k_{20 j}$ is the fixed effect of the $\mathrm{jth}$ class of $\mathrm{k}_{20}(\mathrm{j}=7$ classes $) ; \mathrm{a}_{30 \mathrm{k}}$ is the fixed effect of the kth class of $\mathrm{a}_{30}$ (k=7 classes); Farm $\mathrm{k}_{1}$ is the random effect of the lth farm $(1=1$ to 35$)$; Breed $_{m}$ is the random effect of the $\mathrm{mth}$ breed $(\mathrm{m}=$ Saanen, Camosciata delle Alpi, Murciano-Granadina, Maltese, Sarda, and Sarda Primitiva); Animal $_{n}$ is the random effect of the nth class of animal ( $\mathrm{n}=1$ to 560); Glass Tube $_{o}$ is the random effect of the oth glass tube of the rack of the lactodynamograph instrument (o $=1$ to 8$)$; and $\mathrm{e}_{\text {efghijklmnop }}$ is the random residual $\sim N\left(\mathbf{0}, \sigma_{e}^{2}\right)$, where $\sigma$ is the standard deviation.

A model derived from [M1], without the effects of MCP (RCT, $k_{20}$, and $a_{30}$ ), was used to test the effect of $\mathrm{CF}_{\mathrm{t}}$ parameters $\left(\mathrm{RCT}_{\mathrm{eq}}, \mathrm{k}_{\mathrm{CF}}\right.$, and $\left.\mathrm{CF}_{\mathrm{P}}\right)$ on cheesemaking traits:

$$
\begin{aligned}
& \mathrm{Y}_{\text {efghijklmnop }}=\mu+\mathrm{DIM}_{\mathrm{e}}+\text { Parity }_{\mathrm{f}}+\text { Fat }_{\mathrm{g}}+\text { Protein }_{\mathrm{h}} \\
& +\mathrm{RCT}_{\text {eqi }}+\mathrm{k}_{\mathrm{CFj}}+\mathrm{CF}_{\mathrm{Pk}}+\text { Farm }_{\mathrm{l}}+\text { Breed }_{\mathrm{m}} \\
& + \text { Animal }_{\mathrm{n}}+\text { Glass Tube }_{\mathrm{o}}+\mathrm{e}_{\text {efghijklmnop}} \text {, }
\end{aligned}
$$

in which $\mathrm{RCT}_{\text {eqi }}$ is the fixed effect of the ith class of $\mathrm{RCT}_{\mathrm{eq}}\left(\mathrm{i}=7\right.$ classes); $\mathrm{k}_{\mathrm{CFj}}$ is the fixed effect of the jth class of $\mathrm{k}_{\mathrm{CF}}$ ( $\mathrm{j}=1$ to 7 classes); and $\mathrm{CF}_{\mathrm{Pk}}$ is the fixed effect of the kth class of $\mathrm{CF}_{\mathrm{P}}$ ( $\mathrm{k}=7$ classes). Unlike previous papers based on the same data set, specifically dealing with the effect of the 6 breeds of goats, in this study breed was considered as a random effect. This allowed us to quantify the variance component due to breed and to obtain estimates of the relationships between $\mathrm{MCP}$ and $\mathrm{CF}_{\mathrm{t}}$ traits, and \%CY and \%REC traits corrected for a breed effect and not specifically related to the different 6 breeds.

Traditional $\mathrm{MCP}$ and $\mathrm{CF}_{\mathrm{t}}$ parameters tested in [M1] and [M2] were not included in a single model, so as to avoid multi-collinearity problems. Each of the 7 classes of RCT, $\mathrm{k}_{20}, \mathrm{a}_{30}, \mathrm{RCT}_{\mathrm{eq}}, \mathrm{k}_{\mathrm{CF}}$, and $\mathrm{CF}_{\mathrm{P}}$ (Supplemental Table S1; https://doi.org/10.3168/jds.2019-16424) was designed on the basis of distribution of the variables: each single class explained $0.5 \mathrm{SD}$ of the variable; the fourth was centered on the mean value; and the first and the seventh represented the tails of the distribution (class 1: $<-1.25 \mathrm{SD}$; class $2:-1.25$ to $-0.75 \mathrm{SD}$; class 3: -0.75 to $-0.25 \mathrm{SD}$; class $4:-0.25$ to $+0.25 \mathrm{SD}$; class 
5: +0.25 to $+0.75 \mathrm{SD}$; class $6:+0.75$ to $+1.25 \mathrm{SD}$; class $7:>+1.25 \mathrm{SD})$. Orthogonal polynomial contrasts (linear, quadratic, and cubic patterns) were performed between the least squared means of $\mathrm{RCT}, \mathrm{k}_{20}, \mathrm{a}_{30}$, $\mathrm{RCT}_{\mathrm{eq}}, \mathrm{k}_{\mathrm{CF}}$, and $\mathrm{CF}_{\mathrm{P}}$ classes to investigate whether the differences among the classes of a specific trait were due to a continuous pattern and whether the shape of this pattern was different among traits. All fixed effects and orthogonal contrasts have been tested using the variance of animal as the error line, to avoid inflated degrees of freedom and overfitted $F$-statistics. Pearson product-moment correlations were performed between milk coagulation traits and cheese-making traits.

\section{RESULTS AND DISCUSSION}

\section{Correlations of Coagulation Traits with Component Recovery and Cheese Yield}

Table 1 reports the mean and standard deviation (SD) and the Pearson product-moment correlations of individual traditional single-point $\mathrm{MCP}$ and $\mathrm{CF}_{\mathrm{t}}$ parameters, \% REC, \%CY, and $\mathrm{dCY}$ traits of goat milk samples. It is worth noting that 38 of the 42 correlation coefficients between the traditional MCP and the $\mathrm{CF}_{\mathrm{t}}$ model parameters on one side and the cheese traits on the other (\%REC and \%CY traits) are significant and favorable (negative for time intervals and positive for $\mathrm{CF}$ measures). These findings confirm previous results from bovine milk (Cecchinato and Bittante, 2016).
The comparison of the results regarding the 2 groups of traits describing milk coagulation, $\mathrm{MCP}$ and $\mathrm{CF}_{\mathrm{t}}$ model parameters, with cheese yields evidenced that the correlation coefficients of $\mathrm{RCT}_{\mathrm{eq}}$ with cheese traits was characterized by higher values than for the equivalent RCT trait (Table 1). The single-point traits describing curd-firming pattern $\left(\mathrm{k}_{20}\right.$ and $\left.\mathrm{a}_{30}\right)$ could not be directly compared with the other $\mathrm{CF}_{\mathrm{t}}$ model parameters $\left(\mathrm{k}_{\mathrm{CF}}\right.$ and $\mathrm{CF}_{\mathrm{P}}$ ), but the former showed higher values of correlation with cheese traits than did the latter, and this could be attributable to the high interdependence observed among the $3 \mathrm{MCP}$ (Bittante, 2011).

The value of $\% \mathrm{REC}_{\mathrm{FAT}}$ was much more correlated with all coagulative traits than was $\% \mathrm{REC}_{\text {PROTEIN }}$, whereas $\% \mathrm{REC}_{\text {SOLIDS }}$ showed intermediate correlation values. As regards \% CY traits, the solids fraction was more correlated with coagulative traits than was the moisture retained, and the sum of the $2\left(\% \mathrm{CY}_{\mathrm{CURD}}\right)$ was intermediate (Table 1).

On the other hand, the correlation coefficients with dCY showed a different scenario. Except for RCT and $\mathrm{RCT}_{\text {eq }}, 11$ of the 12 coefficients showed significant unfavorable correlation (positive for $\mathrm{k}_{20}$; negative for $\mathrm{a}_{30}$, $\mathrm{k}_{\mathrm{CF}}$, and $\mathrm{CF}_{\mathrm{P}}$ ) between daily cheese yields of the goats on one side and the curd-firming pattern on the other (Table 1).

It is important to highlight that both coagulative and cheese yield traits are normally influenced by milk composition (especially fat and protein composition and content), farm management and feeding, and

Table 1. Mean and SD and Pearson product-moment correlations between individual traditional single-point milk coagulation properties (MCP) and curd-firming over time $\left(\mathrm{CF}_{\mathrm{t}}\right)$ parameters obtained from the modeling of all recorded curd firmness values (120 per milk sample), and component recovery (\%REC), cheese yield $(\% \mathrm{CY})$, and daily cheese yield (dCY) traits of goat milk samples

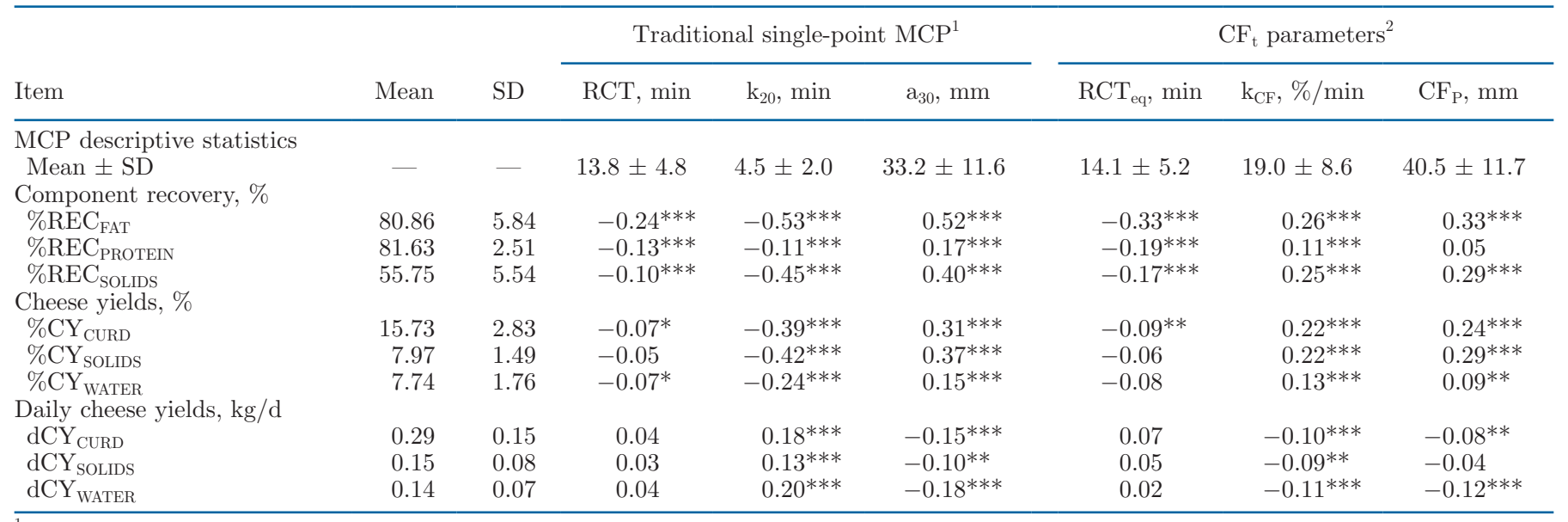

${ }^{1} \mathrm{RCT}=$ measured rennet gelation time; $\mathrm{k}_{20}=$ time interval between gelation and attainment of curd firmness of $20 \mathrm{~mm}$; $\mathrm{a}_{30}=$ curd firmness after 30 min from rennet addition.

${ }^{2} \mathrm{RCT}_{\mathrm{eq}}=\mathrm{RCT}$ estimated according to curd-firming change over time modeling $\left(\mathrm{CF}_{\mathrm{t}}\right) ; \mathrm{k}_{\mathrm{CF}}=$ curd-firming instant rate constant; $\mathrm{CF}_{\mathrm{P}}=$ asymptotic potential curd firmness.

${ }^{*} P<0.05 ;{ }^{* *} P<0.01 ;{ }^{* * *} P<0.001$. 
animals' individual traits (breed, age, lactation stage). This means that the Pearson correlations quantify the combined covariation of all these factors and cannot give us an estimate of the proper effect of a coagulative trait on a cheese yield trait per se (corrected for all the other factors involved).

\section{Effects of Non-Coagulative Factors on Component Recovery and Cheese Yield}

All the main sources of variation, and not only the coagulative traits (model [M1] with the 3 traditional $\mathrm{MCP}$ and model [M2] with the $3 \mathrm{CF}_{\mathrm{t}}$ model parameters), were included in the statistical mixed models to quantify the true contribution of each source on goat cheese traits. The objective of this study was focused on the relationships between coagulative traits and cheese traits, so the other non-coagulative factors affecting cheese traits were considered as nuisance factors, to be removed in order to obtain a specific effect of coagulative traits.

The proportion of variance of cheese traits explained by the random effects included in both models [M1] and [M2] is depicted in Figure 1. The farm variance accounted for 11 to $21 \%$ of the total variance for $\%$ REC traits, 10 to $29 \%$ for $\% \mathrm{CY}$ traits, and 32 to $39 \%$ for $\mathrm{dCY}$ traits. The variability among farms and the results regarding the farm effect are in accordance with the paper by Vacca et al. (2018a). The breed effect accounted for a lower proportion, from about 7 to $13 \%$ for \%REC traits, 3 to $10 \%$ for \% CY traits, and 27 to $37 \%$ for dCY traits. The animal variance was the highest for \%REC and \%CY traits (69 to $81 \%$, and 44 to $76 \%$, respectively) and much lower for dCY traits (31 to $32 \%$ of total variance). This suggests that the improvement of \% REC and \% CY traits is mainly controlled by the genetics of the animal, whereas farming system (i.e., management and feeding) played a much more important role in the level of production. Glass tube had almost no incidence, and residual variance showed high values for \%CY traits (3 to 24\%) and low values for \%REC (0.1 to $2.8 \%)$ and dCY traits (0.1 to $3 \%)$. These results are different from previous findings for other species. Bovine herd date incidence ranges from 11 to $17 \%$ for $\%$ REC traits, from 19 to $29 \%$ for actual $\% \mathrm{CY}$ traits, and from 42 to $46 \%$ for dCY traits (Stocco et al., 2018a). Large difference are found for sheep milk (Cipolat-Gotet et al., 2016a), because the effect of flock is higher than our results for \%REC (13 to 56\%) and \%CY traits (43 to 49\%) and lower for dCY (18 to $42 \%$ ).

The significance of the fixed factors included in the mixed models is shown in Table 2 for model [M1] and Table 3 for [M2], respectively. The stage of lactation showed a minor influence on \% REC $_{\text {PROTEIN }}$ and $\% \mathrm{REC}_{\text {SOLIDS }}$ with both models, whereas parity affected $\% \mathrm{REC}_{\text {PROTEIN }}, \% \mathrm{CY}_{\mathrm{CURD}}$, and, as expected, all $3 \mathrm{dCY}$

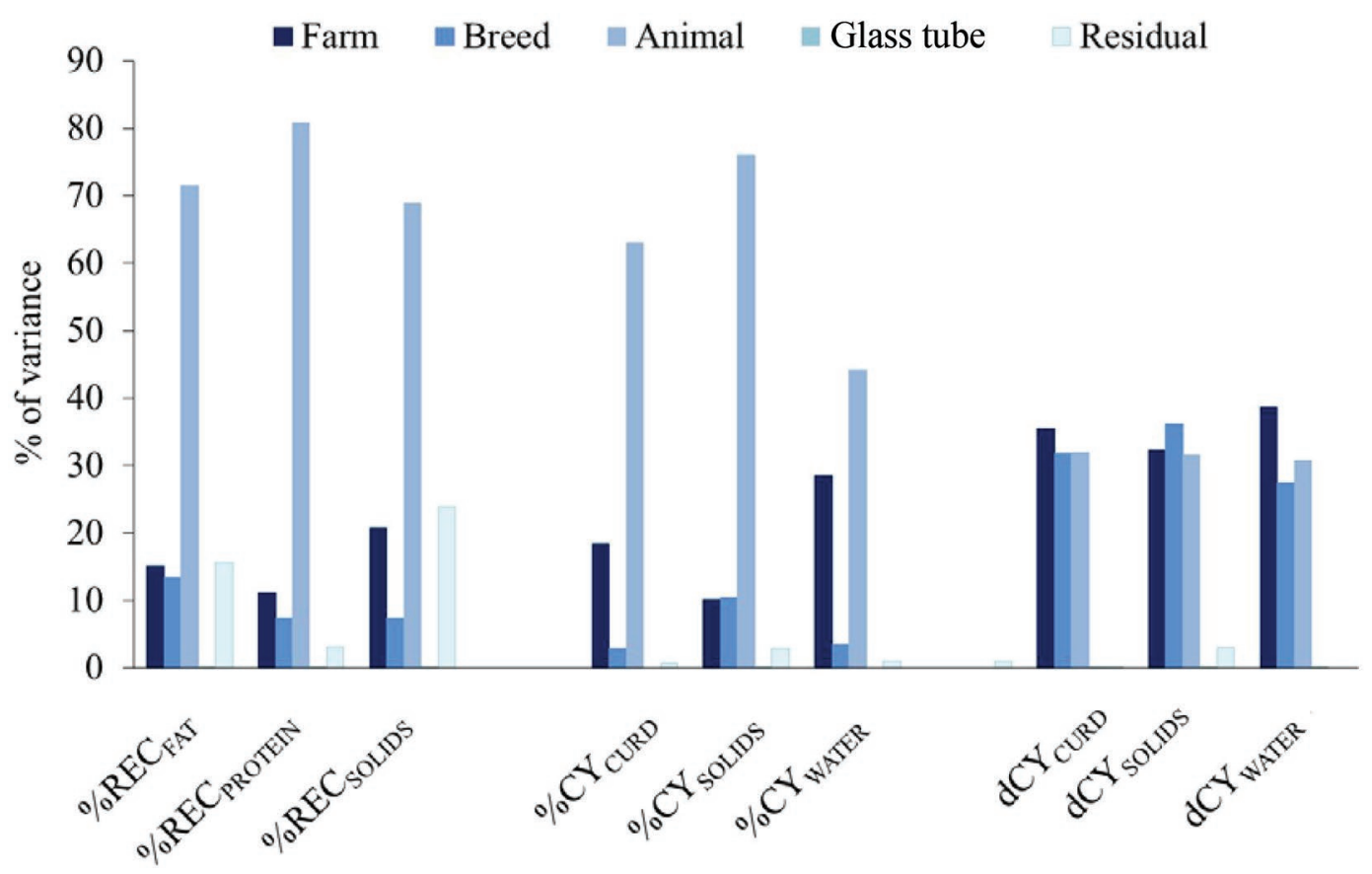

Figure 1. Proportion of variance (in percentage) explained by random effects from models [M1] and [M2] for component recovery (\%REC), cheese yield $(\% \mathrm{CY})$, and daily cheese yield $(\mathrm{dCY})$ traits of milk samples from individual goats $(\mathrm{n}=560)$ of 6 breeds. 
Vacca et al.: GOAT MILK COAGULATION PROPERTIES AND CHEESE-MAKING
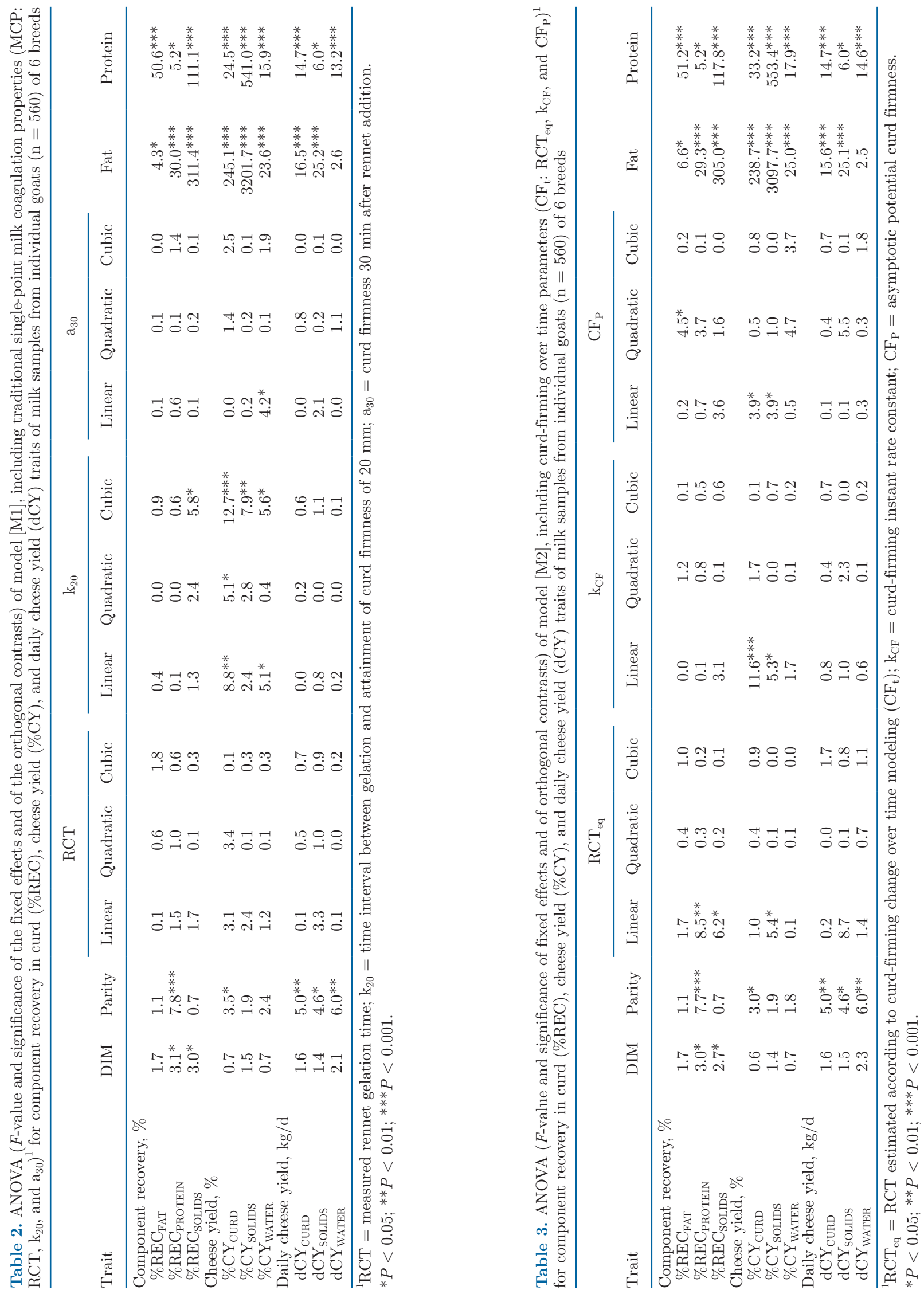

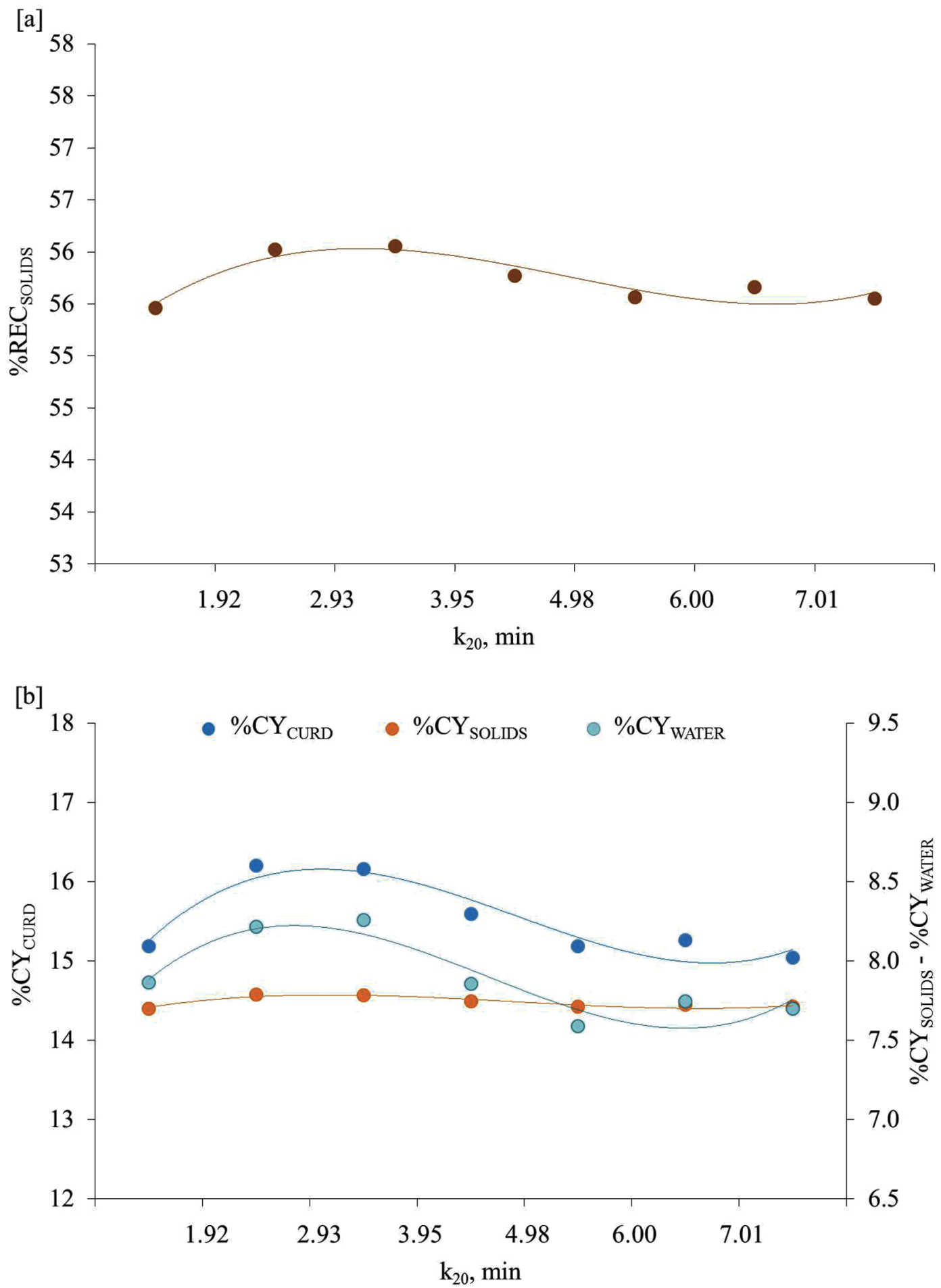

Figure 2. Effect of curd-firming time $\left(\mathrm{k}_{20}\right)$ on percentage of recovery of milk solids, $\%$ REC $\mathrm{SOLIDS}_{\text {(a) }}$ and cheese yield traits, $\% \mathrm{CY}\left(\% \mathrm{CY} \mathrm{CURD}_{\mathrm{B}}\right.$ as the percentage of fresh curd, $\% \mathrm{CY}_{\text {SOLIDS }}$ of $\mathrm{DM}$, and $\% \mathrm{CY}_{\text {WATER }}$ of water retained in curd; b). Details of statistical analysis are shown in Table 2. Effect of curd-firming time $\left(\mathrm{k}_{20}\right)$ on percentage of recovery of milk solids $\left(\% \mathrm{REC}_{\text {SOLIDS}} ; \mathrm{a}\right)$ and percentage cheese yield of curd $(\% \mathrm{CY}$; b). Details of statistical analysis are shown in Table 2 . 
traits. The effects of milk fat and protein content were particularly important on all cheese traits, with the exception only of the effect of fat content on dCY $Y_{\text {WATER }}$. This result is in agreement with a previous study by Pazzola et al. (2019) about the effect of milk composition on goat cheese-making traits. A possible explanation regarding the non-significant effect of fat content on water retention in cheese could be the very low variability of $\mathrm{dCY}_{\text {WATER }}(\mathrm{SD}=0.07)$.

The positive relationship between milk fat and protein contents and \%CY has been previously reported by other studies on goat (Guo et al., 2004; Zeng et al., 2007), sheep (Jaramillo et al., 2008; Manca et al., 2016), cow (Verdier-Metz, et al., 2001), and buffalo milk (Shakerian et al., 2016). As regards \%REC traits, very few studies have investigated the effect of milk composition. Cipolat-Gotet et al. (2018) have described in detail the effect of the different protein fractions of bovine milk, and Sales et al. (2018) have evidenced that, in buffaloes, milk protein is positively associated with recovery of protein and casein in the curd. In sheep, recovery of fat (Jaeggi et al., 2005) and protein in the curd (Pirisi et al., 2000; Jaeggi et al., 2005) have been studied on the basis of somatic cell content or season effects but not milk composition. Cipolat-Gotet et al. (2016b), in a study dealing with phenotypic correlations between cheese-making traits and sheep milk composi- tion, evidence that the correlations among REC traits and milk total solids, fat, protein, and casein are low for $\% \mathrm{REC}_{\text {PRotein }}$ (0.14 to 0.21 ), moderate for $\% \mathrm{REC}_{\mathrm{FAT}}$ (0.27 to 0.37 ), and high for $\% \mathrm{REC}_{\text {SOLIDS }}$ (0.64 to 0.82 ).

\section{Effects of Traditional Single-Point MCP on Component Recovery and Cheese Yield}

The $F$-values and significance of the effects, and the orthogonal contrasts for traditional single-point milk coagulation properties (model [M1]), for \%REC, \%CY, and dCY traits are reported in Table 2. Because composition of milk affects both cheese yield and coagulation ability of milk (Jaramillo et al., 2008; Pazzola et al., 2014; Amalfitano et al., 2019), we corrected the model for milk fat and protein, to quantify the true independent effect of $\mathrm{MCP}$ and $\mathrm{CF}_{\mathrm{t}}$ parameters on the considered traits. The studies that have investigated the effect of coagulation properties on CY have rarely included milk composition in their statistical models, and to our knowledge, no previous study has investigated the effects of 6 different coagulative traits on different measures of cheese yield and recovery of components of goat milk. In some studies describing the associations between bovine MCP and CY, milk samples characterized by short RCT also show higher $\% \mathrm{CY}_{\text {SOLIDS }}$ compared with milk samples characterized

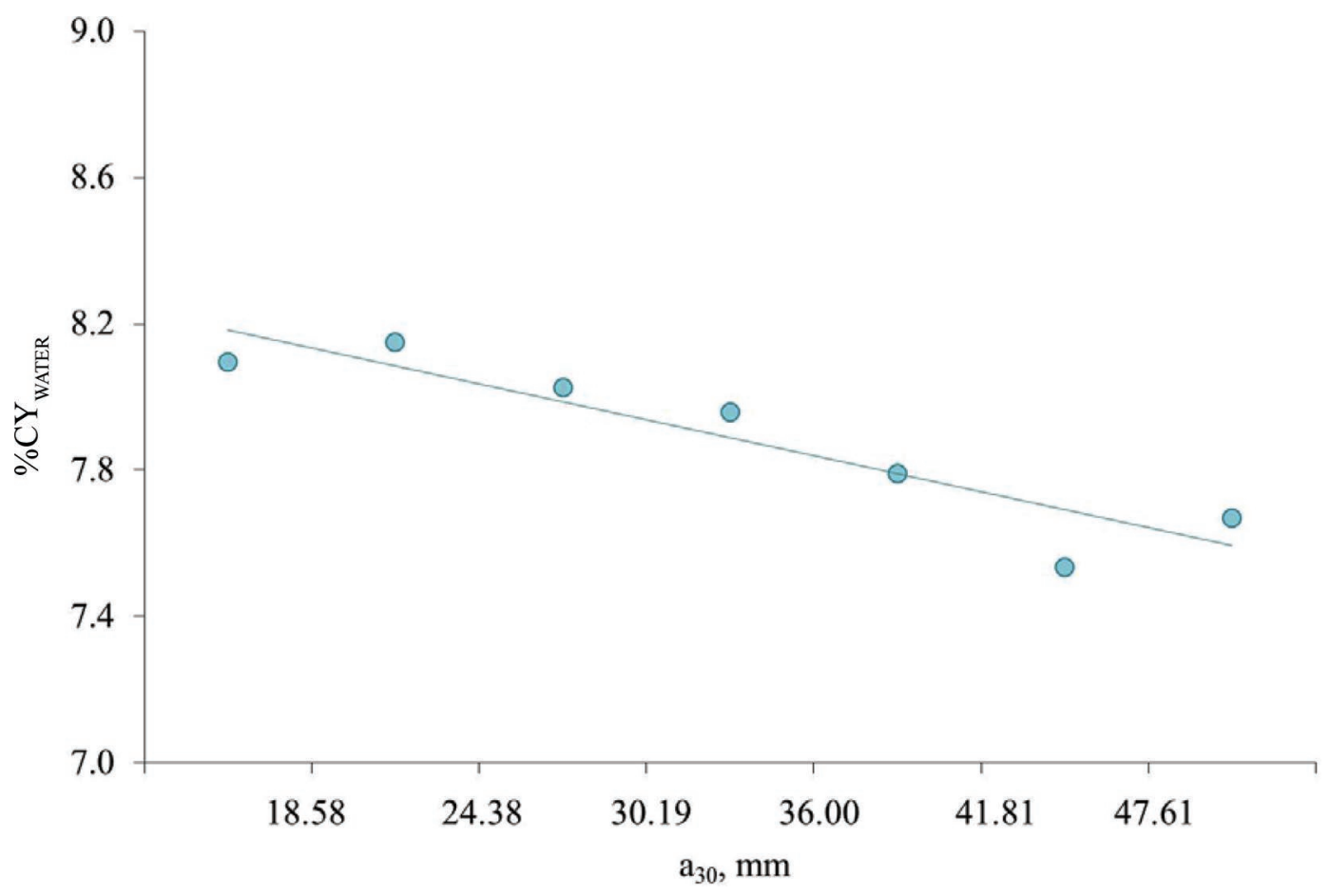
2 .

Figure 3. Effect of curd firmness $\left(\mathrm{a}_{30}\right)$ on percentage of water retained in curd $\left(\% \mathrm{C} \mathrm{Y}_{\text {WATER }}\right)$. Details of statistical analysis are shown in Table 
by longer RCT (Walsh et al., 1998; Buchberger and Dovč, 2000). However, in those studies it is not possible to separate the effect of milk composition (in particular of milk protein and its fractions) from the specific effect of MCP. In some other studies based on cheese-making experiments comparing milk samples characterized by good or poor aptitude to coagulate (Ikonen et al., 1999; Wedholm et al., 2006), associations between MCP and
CY traits have not been clear, especially because the effects of MCP are sometime confounded with the factors responsible for their variation (i.e., milk composition, breed, herd). Hence, information provided by those studies should be considered prudently. Jaramillo et al. (2008), after the inclusion of milk composition in their statistical model, found no correlation for RCT and $\mathrm{a}_{30}$ with cheese yield in sheep milk. Manca et al. (2016), in
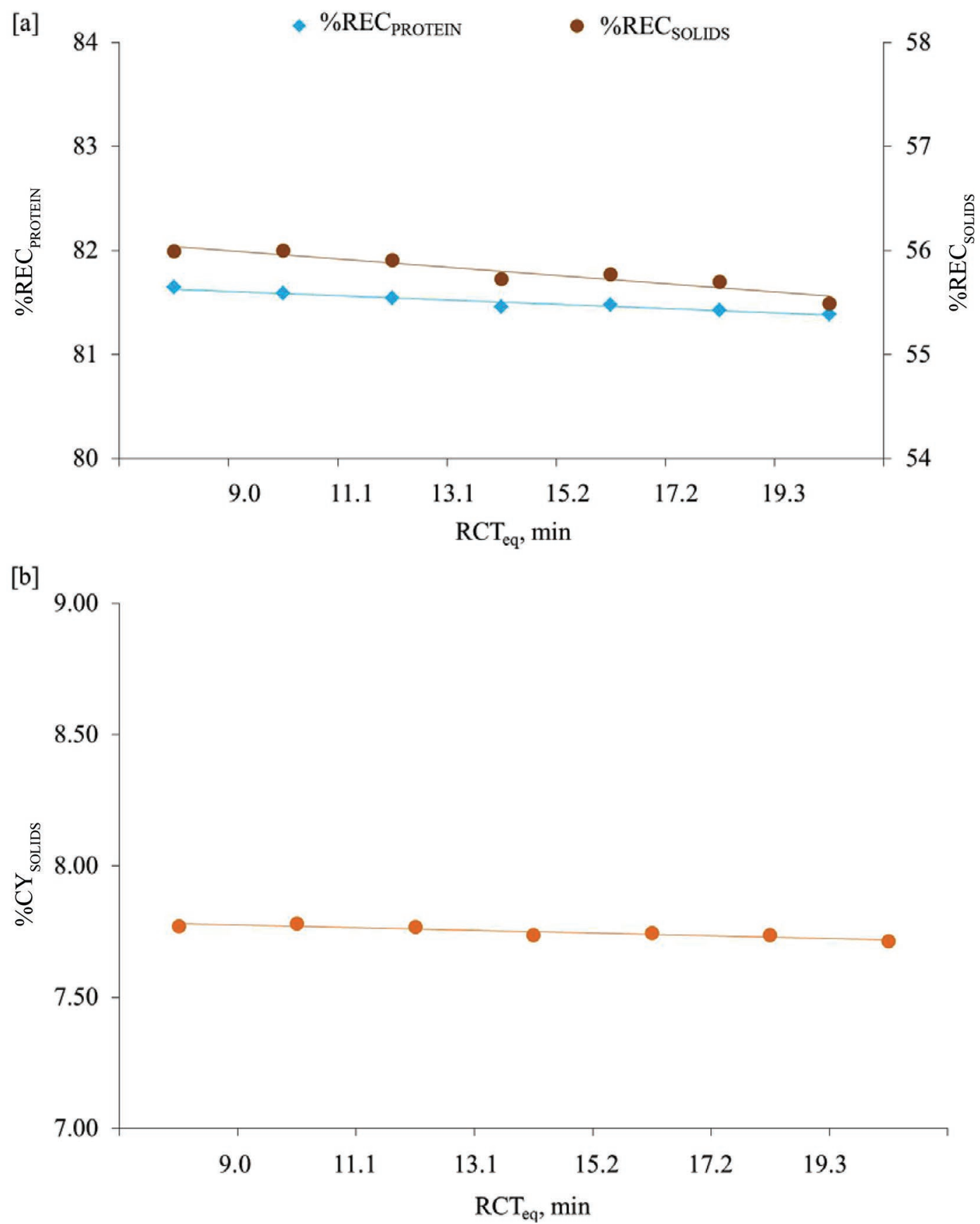

Figure 4. Effect of estimated rennet coagulation time $\left(\mathrm{RCT}_{\text {eq }}\right)$ on percentage of recovery of protein and solids $\left(\% \mathrm{REC}_{\mathrm{PROTEIN}}\right.$ and $\% \mathrm{REC}$ SOLIDS, respectively; a), and percentage of DM in curd (\% $\mathrm{CY}_{\text {SOLIDs; }}$ b). Details of statistical analysis are shown in Table 3. 
their work on multivariate analysis among milk composition, coagulation, and cheese-making traits in sheep milk, found a substantial independence of $\% \mathrm{CY}$ from the traditional MCP and, as expected, large correlations between individual \%CY and milk fat content. The disagreements among the cited studies can be partly attributed to the wide variability observed among studies about experimental conditions and methods.

Among the traditional MCP, the information provided by $\mathrm{k}_{20}$ is very important for the cheese-making process, as it indicates the optimal moment for curd cutting (Bynum and Olson, 1982). It represents the first step of the progressive dehydration by which milk components are recovered and concentrated in the cheese curd. In this study, curd-firming time induced a cubic pattern on $\% \mathrm{REC}_{\text {SOLIDS }}$ (Figure $2 \mathrm{a}$ ) with an optimum value between 2 and 4 min, which was recorded for all 3 \% CY traits (Figure 2b). Therefore, milk samples characterized by very early (under approximately $2 \mathrm{~min}$ ) or late curd-firming (over approximately $4 \mathrm{~min}$ ) were associated with lower recovery of total solids in the curd and a general decrease of \%CY. Some previous studies have reported that cutting the curd when it is too soft results in a decreased $\% \mathrm{CY}$, and delaying the cutting time tends to induce the opposite effect (Lawrence, 1991; Fagan et al., 2007). However, the increase of CY after a delayed cutting time is most probably due to increased water retention in the curd $\left(\% \mathrm{CY}_{\text {WATER }}\right)$ and not to improvement of component recovery (Martin et al., 1997; Castillo et al., 2006).

Curd firmness was negatively associated with $\% \mathrm{CY}_{\text {WATER }}$ (Figure 3). The contrary is found for bovines by Cecchinato and Bittante (2016), as \%CY WATER is positively associated with higher curd firmness parameters (i.e., curd firmness at 30 and $45 \mathrm{~min}$, and $\mathrm{CF}_{\mathrm{P}}$ ). In bovine milk, Aleandri et al. (1989) have found that the effect of curd firmness on CY during production of Parmesan cheese is affected by the fat content, with a favorable effect for milk with low fat content and unfavorable for high fat content. Water retention in cheese is influenced by several factors, including the breed of the animal (Vacca et al., 2018b), processing conditions (Remeuf et al., 1991), and the concentrations of milk fat and protein (Pazzola et al., 2019).

\section{Effects of Estimated $\mathrm{CF}_{t}$ Parameters on Component Recovery and Cheese Yield}

In the literature no information is available on the effects of $\mathrm{CF}_{\mathrm{t}}$ parameters on goat cheese-making traits. Because technical improvements have been achieved for the Formagraph instrument, the information obtained at any time during coagulation can now be stored and easily accessed. That information, if properly modeled, is more informative than the traditional MCP for both cows (Malchiodi et al., 2014; Stocco et al., 2017) and

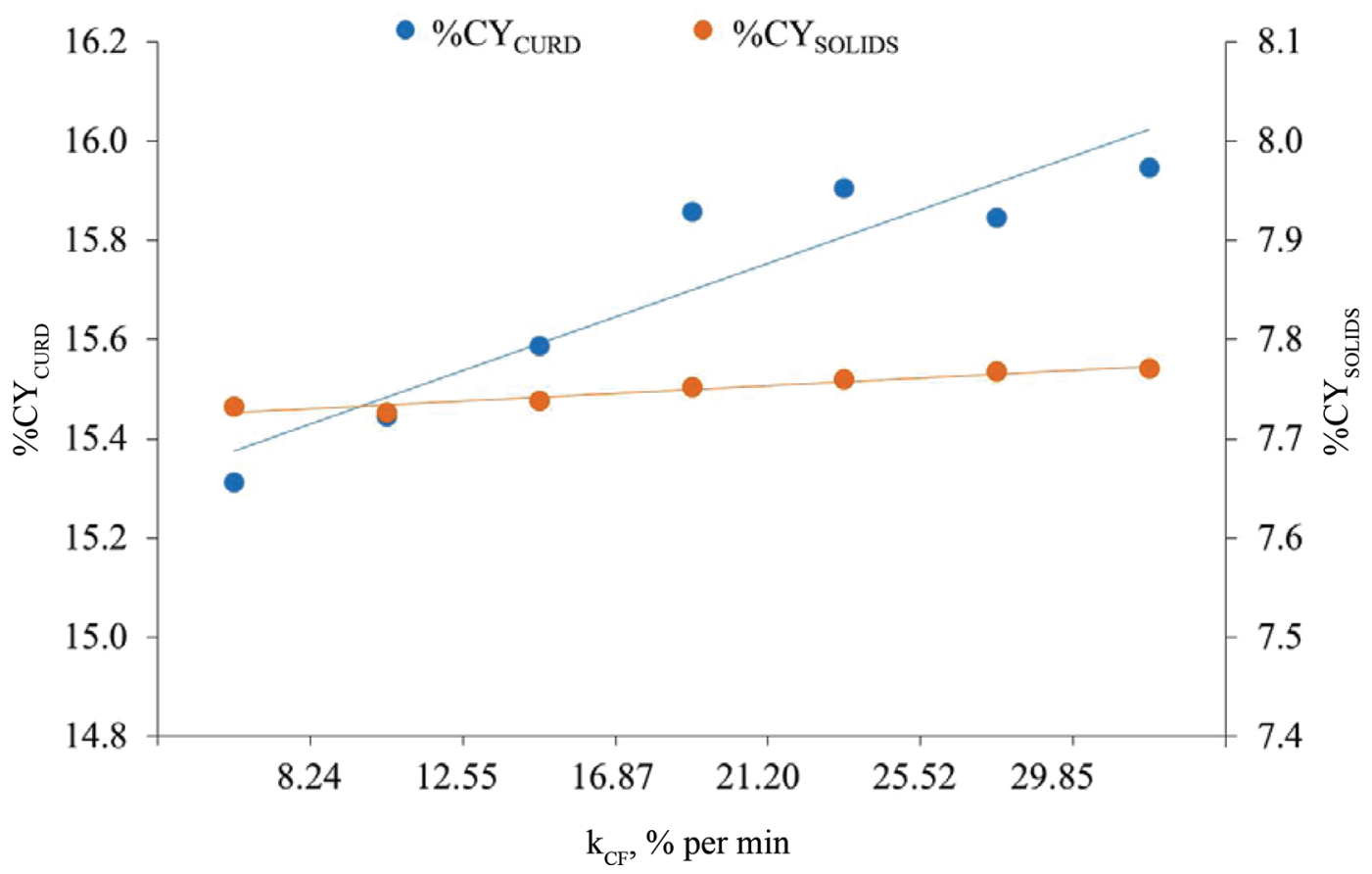

Figure 5. Effect of curd-firming rate constant $\left(\mathrm{k}_{\mathrm{CF}}\right)$ on percentage of fresh curd and DM in curd $\left(\% \mathrm{CY}_{\mathrm{CURD}}, \%_{\mathrm{CY}} \mathrm{SOLIDS}\right)$. Details of statistical analysis are shown in Table 3. 
small ruminants (Vacca et al., 2015; Pazzola et al., 2018). Moreover, the 3 estimated parameters are less interdependent than traditional MCP, and the practical and scientific utility of the parameters, the relationship among them, and their genetic and genomic aspects have been also investigated (Cecchinato and Bittante, 2016; Dadousis et al., 2017). The suitability of information from all points recorded by the Formagraph rather

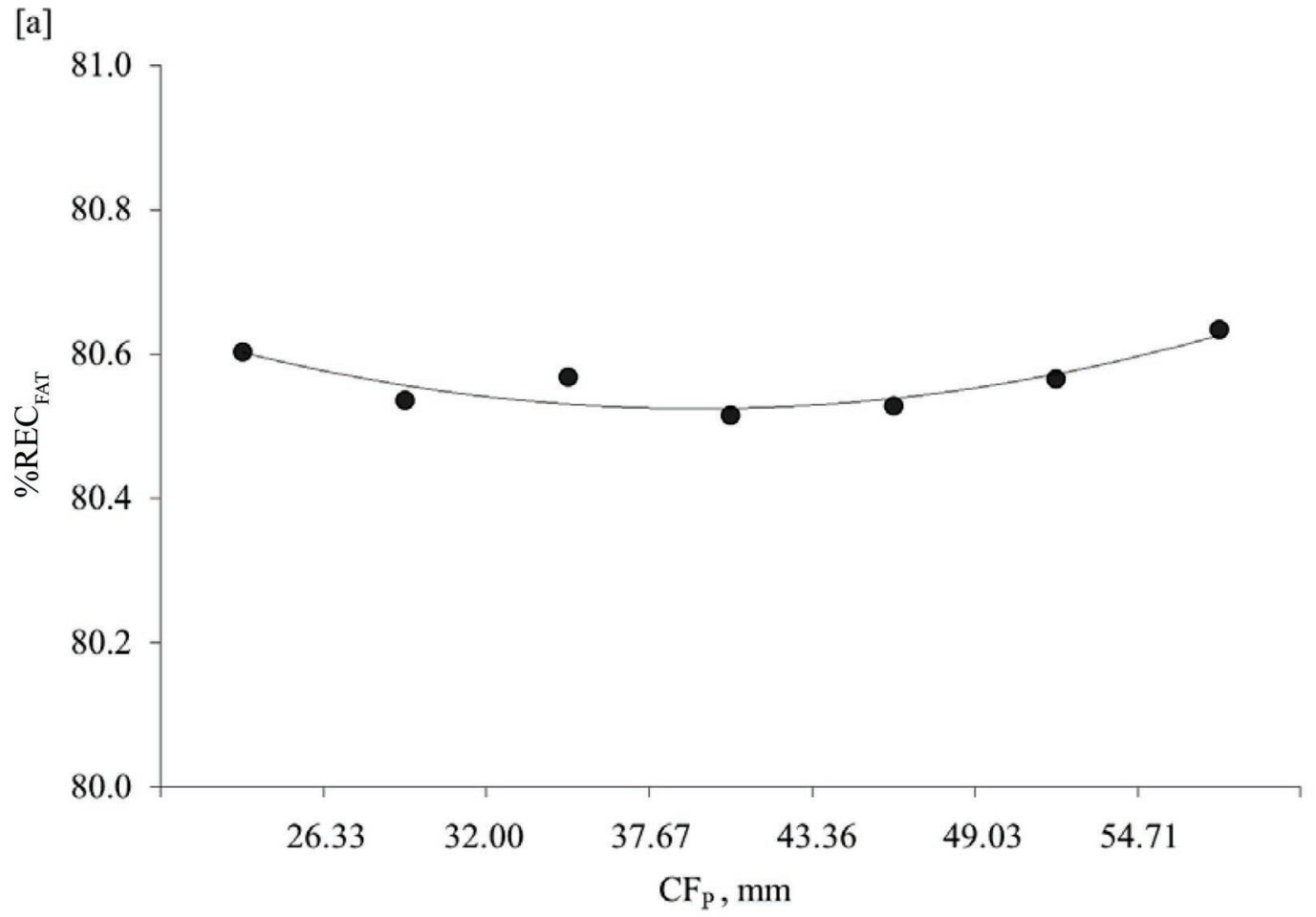

[b]

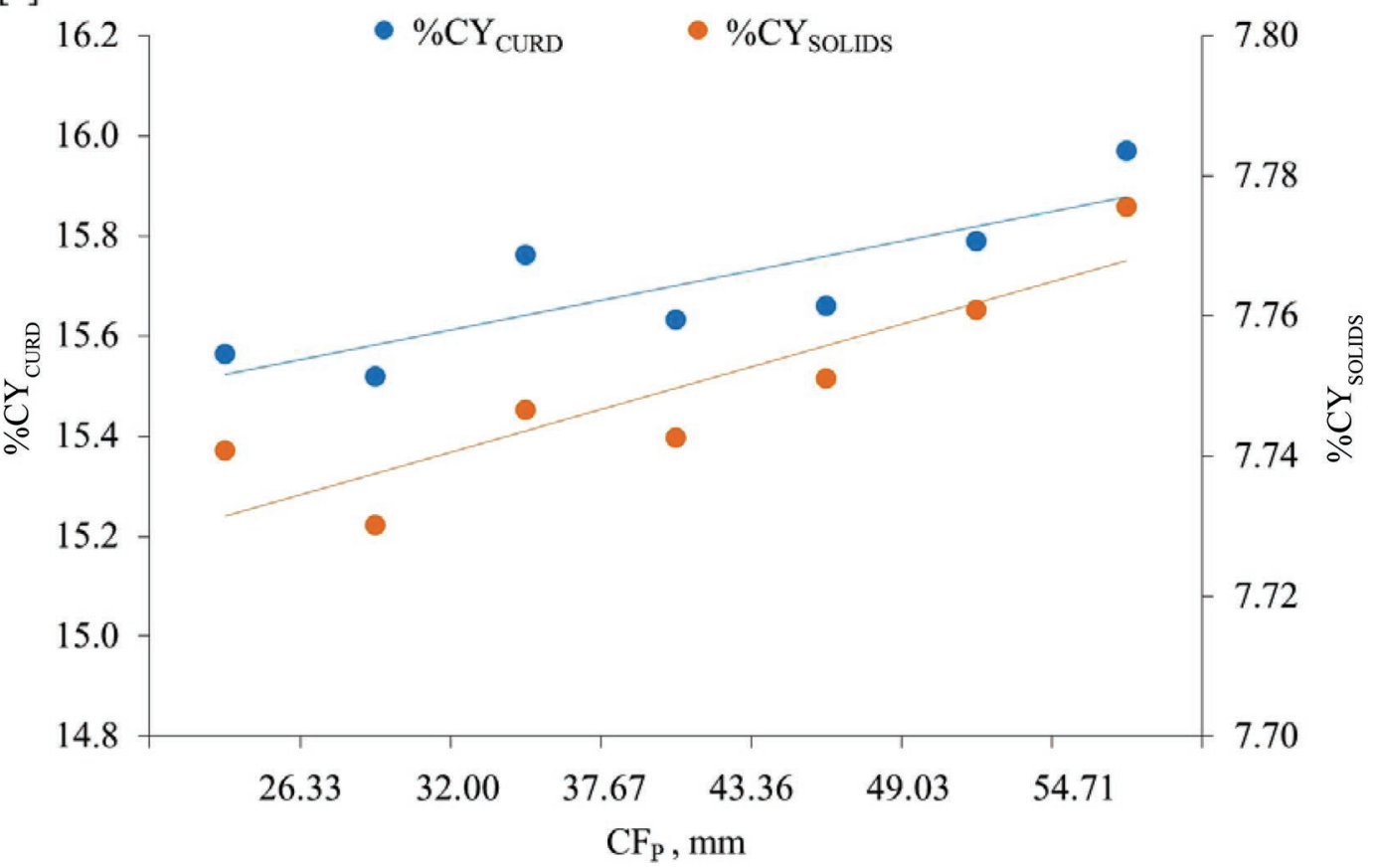

Figure 6. Effect of asymptotic potential curd firmness $\left(\mathrm{CF}_{\mathrm{P}}\right)$ on percentage of recovery of fat $\left(\% \mathrm{REC}_{\mathrm{FAT}}\right.$; a) and percentage of fresh curd $\left(\% \mathrm{CY}_{\mathrm{CURD}} ; \mathrm{b}\right)$. Details of statistical analysis are shown in Table 3. 
than via single points was evidenced by comparison of the effects of traditional RCT (Table 2) with estimated $\mathrm{RCT}_{\text {eq }}$ (Table 3 ). Unlike RCT, longer $\mathrm{RCT}_{\text {eq }}$ values were associated with lower protein and total solids recovered in the curd (Figure $4 \mathrm{a}$ ) and with lower $\% \mathrm{CY}_{\text {SOLIDS }}$ (Figure $4 \mathrm{~b})$. Data provided by $\mathrm{RCT}_{\mathrm{eq}}$ were more effective than those provided by traditional single-point RCT in explaining the cheese-making process and yield. In addition, $\mathrm{k}_{\mathrm{CF}}$ influenced $\% \mathrm{CY}_{\mathrm{CURD}}$ and $\% \mathrm{CY}_{\text {SOLIDS }}$ (Figure 5). In accordance with a previous study reporting that $\mathrm{k}_{\mathrm{CF}}$ is positively affected by fat content (Stocco et al., 2018b), we can speculate that because of the tightening of the casein net, a faster increase of curd-firming rate allowed more total solids to be retained in the curd, with consequent increase of $\% \mathrm{CY}_{\mathrm{CURD}}$. The asymptotic $\mathrm{CF}_{\mathrm{P}}$, which represents the maximum potential curd firmness of a given sample after infinite time, was positively associated with \% REC $_{\mathrm{FAT}}$ (quadratic trend; Figure 6a) and with \% CY of fresh curd and solids (linear trend; Figure $6 \mathrm{~b}$ ). The difference in mean values between $\mathrm{CF}_{\mathrm{P}}$ and $\mathrm{a}_{30}$ confirms that the lower value of $\mathrm{a}_{30}$ is due to the short time available for the curd-firming process to reach its potential. Moreover, $\mathrm{a}_{30}$ is related to RCT, as the delay of gelation time causes a reduction of the 30-min interval from gelation available for curd-firming (Caballero-Villalobos et al., 2018). Hence, the negative correlation between $\mathrm{RCT}$ and $\mathrm{a}_{30}$ could be attributable to the effect of the decreasing time available for measuring CF rather than to an intrinsic smaller potential of $\mathrm{CF}$ in late-coagulating milk samples. Unlike $\mathrm{a}_{30}, \mathrm{CF}_{\mathrm{P}}$ is not dependent on RCT.

Because of the much larger level of independence among $\mathrm{CF}_{\mathrm{t}}$ parameters, these traits can also be more easily characterized from the perspective of possible application at the industry level. A recent study on this topic among bovine milk samples revealed that the $\mathrm{CF}_{\mathrm{t}}$ parameters describing the late part of the coagulation process (in our case, only $\mathrm{CF}_{\mathrm{P}}$ ) are more genetically correlated with $\mathrm{CY}$ traits than are the traditional MCP (Cecchinato and Bittante, 2016). Moreover, we may expect further progress in the dairy sector through the use of Fourier-transform infrared spectroscopy, coupled with chemometric models, to predict coagulation traits and include this information in the milk payment system (Ferragina et al., 2017).

\section{CONCLUSIONS}

Results presented in this study provide new knowledge about the relationships between coagulation and cheese-making traits in goats. The simultaneous inclusion of both milk composition and the information from traditional $\mathrm{MCP}$ and $\mathrm{CF}_{\mathrm{t}}$ parameters in the statistical models were suitable to ascertain the specific effects of coagulation on both \% CY and \%REC traits. In particular, we found an optimum range of $k_{20}$ values for goat milk to obtain the highest recovery of components and $\% \mathrm{CY}_{\text {SOLIDS. }}$. This finding clarifies that high curd firmness associated with high \% CY is not derived only from higher retention of water in the curd. On the contrary, samples with high curd firmness values were characterized by a greater $\% \mathrm{REC}_{\mathrm{FAT}}$, lower $\% \mathrm{CY}_{\mathrm{WATER}}$, and increased $\% \mathrm{CY}_{\mathrm{CURD}}$. The collection of all the available information during the process of milk coagulation and curd-firming evidenced the effect of $\mathrm{RCT}_{\text {eq }}$ on \% REC traits and \% $\mathrm{CY}_{\text {SOLIDS }}$ (which was not revealed for traditional $\mathrm{RCT}$ ), and the positive correlation of the curd-firming instant rate constant with $\% \mathrm{CY}_{\mathrm{CURD}}$

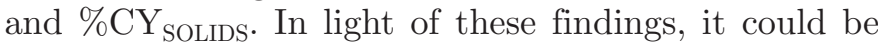
stimulating to hypothesize a quality payment scheme for goat milk that would also include the information provided by coagulation traits, and to address future research to test predictive \% CY and \%REC formulae using rapid and low-cost techniques, such as infrared spectroscopy, to improve the goat dairy industry.

\section{ACKNOWLEDGMENTS}

Research supported by the Regional Government of Sardinia, Cagliari, Italy (Legge Regionale 7/2007; CUP J72I15000030007). The authors thank the participating farmers for giving access to their flocks; the AIPA/ APAs (Provincial Farmers Associations) of Cagliari, Nuoro, Sassari, and Oristano, Italy, and the firms Sepi Formaggi (Marrubiu, Italy) and L'Armentizia Moderna (Guspini, Italy) for their support in sample collection; and the ARA Sardegna (Regional Farmers Association of Sardinia, Cagliari, Italy) for support in chemical milk analysis. The authors state they have no conflicts of interest.

\section{REFERENCES}

Aleandri, R., J. C. Schneider, and L. G. Buttazzoni. 1989. Evaluation of milk for cheese production based on milk characteristics and Formagraph measures. J. Dairy Sci. 72:1967-1975. https://doi .org/10.3168/jds.S0022-0302(89)79319-X.

Amalfitano, N., C. Cipolat-Gotet, A. Cecchinato, M. Malacarne, A. Summer, and G. Bittante. 2019. Milk protein fractions strongly affect the patterns of coagulation, curd firming and syneresis. J. Dairy Sci. 102:2903-2917. https://doi.org/10.3168/jds.2018-15524.

Bencini, R. 2002. Factors affecting the clotting properties of sheep milk. J. Sci. Food Agric. 82:705-719. https://doi.org/10.1002/jsfa 1101 .

Bittante, G. 2011. Modeling rennet coagulation time and curd firmness of milk. J. Dairy Sci. 94:5821-5832. https://doi.org/10.3168/ jds.2011-4514.

Bittante, G., E. Pellattiero, F. Malchiodi, C. Cipolat-Gotet, M. Pazzola, G. M. Vacca, S. Schiavon, and A. Cecchinato. 2014. Quality traits and modeling of coagulation, curd firming, and syneresis of sheep milk of Alpine breeds fed diets supplemented with rumenprotected conjugated fatty acid. J. Dairy Sci. 97:4018-4028. https: //doi.org/10.3168/jds.2013-7345. 
Buchberger, J., and P. Dovč. 2000. Lactoprotein genetic variants in cattle and cheesemaking ability. Food Technol. Biotechnol. 38:9198.

Bynum, D. G., and N. F. Olson. 1982. Influence of curd firmness at cutting on Cheddar cheese yield and recovery of milk constituents. J. Dairy Sci. 65:2281-2291. https://doi.org/10.3168/jds.S0022 -0302(82)82498-3.

Caballero-Villalobos, J., J. M. Perea, E. Angón, R. Arias, and A. Garzón. 2018. Coagulation efficiency and its determinant factors: a case study for Manchega ewe milk in the region of Castilla-La Mancha, Spain. J. Dairy Sci. 101:3878-3886. https://doi.org/10 $.3168 /$ jds.2017-13816.

Caravaca, F., J. L. Ares, J. Carrizosa, B. Urrutia, F. Baena, J. Jordana, B. Badaoui, A. Sanchez, A. Angiolillo, M. Amills, and J. M. Serradilla. 2011. Effects of as1-casein (CSN1S1) and $\kappa$-casein (CSN3) genotypes on milk coagulation properties in MurcianoGranadina goats. J. Dairy Res. 78:32-37. https://doi.org/10.1017/ S002202991000083X

Castillo, M., J. A. Lucey, T. Wang, and F. A. Payne. 2006. Effect of temperature and inoculum concentration on gel microstructure, permeability and syneresis kinetics. Cottage cheese-type gels. Int. Dairy J. 16:153-163. https://doi.org/10.1016/j.idairyj.2005.02 .004 .

Cecchinato, A., and G. Bittante. 2016. Genetic and environmental relationships of different measures of individual cheese yield and curd nutrients recovery with coagulation properties of bovine milk. J. Dairy Sci. 99:1975-1989. https://doi.org/10.3168/jds.2015-9629.

Cipolat-Gotet, C., A. Cecchinato, M. Malacarne, G. Bittante, and A. Summer. 2018. Variations in milk protein fractions affect the efficiency of the cheese-making process. J. Dairy Sci. 101:8788-8804. https://doi.org/10.3168/jds.2018-14503.

Cipolat-Gotet, C., A. Cecchinato, M. Pazzola, M. L. Dettori, G. Bittante, and G. M. Vacca. 2016a. Potential influence of herd and animal factors on the yield of cheese and recovery of components from Sarda sheep milk, as determined by a laboratory bench-top model cheese-making. Int. Dairy J. 63:8-17. https://doi.org/10 .1016/j.idairyj.2016.07.013.

Cipolat-Gotet, C., A. Cecchinato, G. Stocco, and G. Bittante. 2016b. The 9-MilCA method as a rapid, partly automated protocol for simultaneously recording milk coagulation, curd firming, syneresis, cheese yield, and curd nutrients recovery or whey loss. J. Dairy Sci. 99:1065-1082. https://doi.org/10.3168/jds.2015-9734.

Dadousis, C., S. Pegolo, G. J. M. Rosa, D. Gianola, G. Bittante, and A. Cecchinato. 2017. Pathway-based genome-wide association analysis of milk coagulation properties, curd firmness, cheese yield, and curd nutrient recovery in dairy cattle. J. Dairy Sci. 100:1223-1231. https://doi.org/10.3168/jds.2016-11587.

Fagan, C. C., M. Castillo, F. A. Payne, C. P. O'Donnell, and D. J. O'Callaghan. 2007. Effect of cutting time, temperature, and calcium on curd moisture, whey fat losses, and curd yield by response surface methodology. J. Dairy Sci. 90:4499-4512. https://doi.org/ 10.3168/jds.2007-0329.

Ferragina, A., C. Cipolat-Gotet, A. Cecchinato, M. Pazzola, M. L. Dettori, G. M. Vacca, and G. Bittante. 2017. Prediction and repeatability of milk coagulation properties and curd-firming modeling parameters of ovine milk using Fourier-transform infrared spectroscopy and Bayesian models. J. Dairy Sci. 100:3526-3538. https://doi.org/10.3168/jds.2016-12226.

Guo, M., Y. W. Park, P. H. Dixon, J. A. Gilmore, and P. S. Kindstedt. 2004. Relationship between the yield of cheese (Chèvre) and chemical composition of goat milk. Small Rumin. Res. 52:103-107. https://doi.org/10.1016/S0921-4488(03)00247-5.

Ikonen, T., O. Ruottinen, and E. L. Syväoja. 1999. Effect of milk coagulation properties of herd bulk milks on yield and composition of Emmental cheese. Agric. Food Sci. 8:411-422. https://doi.org/ 10.23986/afsci.5638.

Inglingstad, R. A., H. Steinshamn, B. S. Dagnachew, B. Valenti, A. Criscione, E. O. Rukke, T. G. Devold, S. B. Skeie, and G. E. Vegarud. 2014. Grazing season and forage type influence goat milk composition and rennet coagulation properties. J. Dairy Sci. 97:3800-3814. https://doi.org/10.3168/jds.2013-7542.
ISO-IDF (International Organization for Standardization and International Dairy Federation). 2010. Milk and liquid milk products: Determination of total solids content. International Standard ISO 6731 and IDF 21:2010a. ISO, Geneva, Switzerland, and IDF, Brussels, Belgium.

ISO-IDF (International Organization for Standardization and International Dairy Federation). 2013. Milk and liquid milk products: Determination of fat and protein content. International Standard ISO 9622 and IDF 141:2013. ISO, Geneva, Switzerland, and IDF, Brussels, Belgium.

Jaeggi, J. J., W. L. Wendorff, J. Romero, Y. M. Berger, and M. E. Johnson. 2005. Impact of seasonal changes in ovine milk on composition and yield of a hard-pressed cheese. J. Dairy Sci. 88:13581363. https://doi.org/10.3168/jds.S0022-0302(05)72802-2.

Jaramillo, D. P., A. Zamora, B. Guamis, M. Rodrìguez, and A. J. Trujillo. 2008. Cheesemaking aptitude of two Spanish dairy ewe breeds: Changes during lactation and relationship between physico-chemical and technological properties. Small Rumin. Res. 78:48-55. https://doi.org/10.1016/j.smallrumres.2008.04.005.

Johnson, M. E. C. M. Chen, and J. J. Jaeggi. 2001. Effect of rennet coagulation time on composition, yield, and quality of reducedfat Cheddar cheese. J. Dairy Sci. 84:1027-1033. https://doi.org/10 .3168/jds.S0022-0302(01)74562-6.

Lawrence, R. C. 1991. Processing conditions. Pages 64-78 in Factors Affecting the Yield of Cheese. International Dairy Federation, Brussels, Belgium.

Malchiodi, F., A. Cecchinato, M. Penasa, C. Cipolat-Gotet, and G. Bittante. 2014. Milk quality, coagulation properties and curd firmness modeling of purebred Holsteins and first- and second-generation crossbred cows from Swedish Red, Montbéliarde, and Brown Swiss bulls. J. Dairy Sci. 97:4530-4541. https://doi.org/10.3168/ jds.2013-7868.

Manca, M. G., J. Serdino, G. Gaspa, P. Urgeghe, I. Ibba, M. Contu, P. Fresi, and N. P. P. Macciotta. 2016. Derivation of multivariate indices of milk composition, coagulation properties, and individual cheese yield in dairy sheep. J. Dairy Sci. 99:4547-4557. https://doi .org/10.3168/jds.2015-10589.

Martin, B., J.-F. Chamba, J.-B. Coulon, and E. Perreard. 1997. Effect of milk chemical composition and clotting characteristics on chemical and sensory properties of Reblochon de Savoie cheese. J. Dairy Res. 64:157-162. https://doi.org/10.1017/S0022029996001975.

McMahon, D. J., and R. J. Brown. 1982. Evaluation of Formagraph for comparing rennet solutions. J. Dairy Sci. 65:1639-1642. https: //doi.org/10.3168/jds.S0022-0302(82)82390-4.

Mestawet, T. A., A. Girma, T. Adnoy, T. G. Devold, and G. E. Vegarud. 2013. Newly identified mutations at the CSN1S1 gene in Ethiopian goats affect casein content and coagulation properties of their milk. J. Dairy Sci. 96:4857-4869. https://doi.org/10.3168/ jds.2012-6467.

Ng-Kwai-Hang, K. F., I. Politis, R. I. Cue, and A. S. Marziali. 1989. Correlations between coagulation properties of milk and cheese yielding capacity and cheese composition. Can. Inst. Food Sci. Tech. J. 22:291-294. https://doi.org/10.1016/S0315-5463(89)70397 -7 .

Pazzola, M., M. L. Dettori, E. Pira, A. Noce, P. Paschino, and G. M. Vacca. 2014. Effect of polymorphisms at the casein gene cluster on milk renneting properties of the Sarda goat. Small Rumin. Res. 117:124-130. https://doi.org/10.1016/j.smallrumres.2013.12.004.

Pazzola, M., G. Stocco, M. L. Dettori, C. Cipolat-Gotet, G. Bittante, and G. M. Vacca. 2018. Modeling of coagulation, curd firming, and syneresis of goat milk. J. Dairy Sci. 101:7027-7039. https:// doi.org/10.3168/jds.2018-14397.

Pazzola, M., G. Stocco, P. Paschino, M. L. Dettori, C. Cipolat-Gotet, G. Bittante, and G. M. Vacca. 2019. Effect of goat milk composition on cheese-making traits and daily cheese productions. J. Dairy Sci. 102:3947-3955. https://doi.org/10.3168/jds.2018-15397.

Pirisi, A., G. Piredda, M. Corona, M. Pes, S. Pintus, and A. Ledda. 2000. Influence of somatic cell count on ewe's milk composition, cheese yield and cheese quality. Pages 47-59 in Proc. 6th Great Lakes Dairy Sheep Symp., Guelph, Ontario, Canada. 
Remeuf, F., V. Cossin, C. Dervin, J. Lenoir, and R. Tomassone. 1991. Relationships between physicochemical characteristics of milks and their cheese-making properties. Lait 71:397-421. https://doi org/10.1051/lait:1991431.

Sales, D. C., A. H. N. Rangel, S. A. Urbano, H. Tonhati, J. G. B. Galvão Júnior, M. M. Guilhermino, E. M. Aguiar, and M. F. Bezerra. 2018. Buffalo milk composition, processing factors, whey constituents recovery and yield in manufacturing Mozzarella cheese. Food Sci. Technol. (Campinas) 38:328-334. https://doi .org/10.1590/1678-457x.04317.

Shakerian, M., H. Kiani, and M. R. Ehsani. 2016. Effect of buffalo milk on the yield and composition of buffalo feta cheese at various processing parameters. Food Biosci. 15:110-117. https://doi.org/ 10.1016/j.fbio.2016.06.002.

Stocco, G., C. Cipolat-Gotet, T. Bobbo, A. Cecchinato, and G. Bittante. 2017. Breed of cow and herd productivity affect milk composition and modeling of coagulation, curd firming and syneresis. J. Dairy Sci. 100:129-145. https://doi.org/10.3168/jds.2016-11662.

Stocco, G., C. Cipolat-Gotet, V. Gasparotto, A. Cecchinato, and G. Bittante. 2018a. Breed of cow and herd productivity affect milk nutrient recovery in curd, and cheese yield, efficiency and daily production. Animal 12:434-444. https://doi.org/10.1017/ S1751731117001471.

Stocco, G., M. Pazzola, M. L. Dettori, P. Paschino, G. Bittante, and G. M. Vacca. 2018b. Effect of composition on coagulation, curdfirming and syneresis of goat milk. J. Dairy Sci. 101:9693-9702. https://doi.org/10.3168/jds.2018-15027.

Vacca, G. M., M. Pazzola, M. L. Dettori, E. Pira, F. Malchiodi, C. Cipolat-Gotet, A. Cecchinato, and G. Bittante. 2015. Modeling of coagulation, curd firming and syneresis of milk from Sarda ewes. J. Dairy Sci. 98:2245-2259. https://doi.org/10.3168/jds.2014-8902.

Vacca, G. M., G. Stocco, M. L. Dettori, E. Pira, G. Bittante, and M. Pazzola. 2018a. Milk yield, quality and coagulation properties of six breeds of goats: Environmental and individual variability. J. Dairy Sci. 101:7236-7247. https://doi.org/10.3168/jds.2017-14111.

Vacca, G. M., G. Stocco, M. L. Dettori, A. Summer, C. Cipolat-Gotet, G. Bittante, and M. Pazzola. 2018b. Cheese yield, cheese-making efficiency, and daily production of 6 breeds of goats. J. Dairy Sci. 101:7817-7832. https://doi.org/10.3168/jds.2018-14450.

Verdier-Metz, I., J.-B. Coulon, and P. Pradel. 2001. Relationship between milk fat and protein contents and cheese yield. Anim. Res. 50:365-371. https://doi.org/10.1051/animres:2001138.

Walsh, C. D., T. P. Guinee, W. D. Reville, D. Harrington, J. J. Murphy, B. T. O'Kennedy, and R. J. FitzGerald. 1998. Influence of $\kappa$-casein genetic variant on rennet gel microstructure, Cheddar cheesemaking properties and casein micelle size. Int. Dairy J. 8:707-714. https://doi.org/10.1016/S0958-6946(98)00103-4.

Wedholm, A., L. B. Larsen, H. Lindmark-Månsson, A. H. Karlsson, and A. Andrén. 2006. Effect of protein composition on the cheesemaking properties of milk from individual dairy cows. J. Dairy Sci. 89:3296-3305. https://doi.org/10.3168/jds.S0022-0302(06)72366 $-9$.

Zeng, S. S., K. Soryal, B. Fekadu, B. Bah, and T. Popham. 2007. Predictive formulae for goat cheese yield based on milk composition. Small Rumin. Res. 69:180-186. https://doi.org/10.1016/j .smallrumres.2006.01.007.

\section{ORCIDS}

Giuseppe M. Vacca @ \ttps://orcid.org/0000-0003-3110-5211 Giorgia Stocco @ https://orcid.org/0000-0002-6786-9806 Maria L. Dettori (ㅇ https://orcid.org/0000-0001-5413-0335 Giovanni Bittante (ㄴ) https://orcid.org/0000-0001-7137-7049 Michele Pazzola @ https://orcid.org/0000-0001-5685-0416 